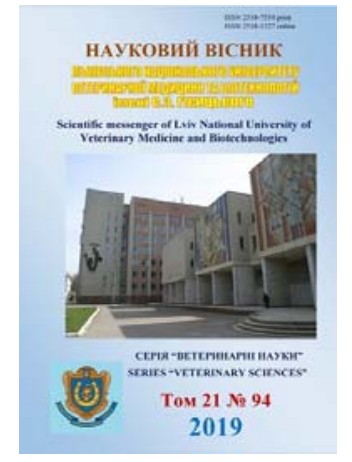

\author{
Науковий вісник Аьвівського національного університету \\ ветеринарної медицини та біотехнологій імені С.3. Гжицького. \\ Серія: Ветеринарні науки \\ Scientific Messenger of Lviv National University \\ of Veterinary Medicine and Biotechnologies. \\ Series: Veterinary sciences
}

ISSN 2518-7554 print ISSN 2518-1327 online doi: $10.32718 /$ nvlvet 9422

http://nvlvet.com.ua

\title{
Veterinary Medicine and the Use of Medicinal Plants
}

\author{
I. Salamon ${ }^{1}$, M. Hrytsyna ${ }^{2}$ \\ ${ }^{1}$ University of Presov in the city of Presov, Slovak Republic \\ ${ }^{2}$ Stepan Gzhytskyi National University of Veterinary Medicine and Biotechnologies Lviv, Ukraine
}

Article info

Received 17.04.2019

Received in revised form 20.05.2019

Accepted 21.05.2019

University of Presov, 15, $17^{\text {th }}$ November St., SK-080 01, Presov, Slovak Republic.

Tel.: +421-51-757-06-62

E-mail:ivan.salamon@unipo.sk

Stepan Gzhytskyi National University of Veterinary Medicine and Biotechnologies Lviv,

Pekarska Str., 50, Lviv, 79010, Ukraine.

Tel.:+38-097-561-52-30 E-mail:hrytsynamr@gmail.com

Salamon, I., \& Hrytsyna, M. (2019). Veterinary Medicine and the Use of Medicinal Plants. Scientific Messenger of Lviv National University of Veterinary Medicine and Biotechnologies. Series: Veterinary sciences, 21(94), 121-126. doi: 10.32718/nvlvet9422

The article deals with the history of development of veterinary medicine in the Eastern Europe (Austria-Hungary) and Galicia from the Middle Ages to our days. Particular attention is paid to the history of use of plants in veterinary practice. Herbal treatment of animals in the past times was described in Martin Cech's book The book of Horses Treatment (Budapest, 1797). An analysis of modern literature was conducted with the issue of use of plants in veterinary medicine. Basically, it is the use of phytodactyls for feed as an alternative to antibiotics, dyes or other synthetic medicines in pig breeding, poultry farming, fish farming, dairy cattle-breeding and for reducing the bacteriological contamination of food, feed additives and veterinary drugs as well. These actions ensure the ecological safety of livestock products. In modern veterinary plants and their extracts are used as phytodactyls for feed, in particular: Silybum marianum, Echinacea purpurea, Tagetes erecta that increase chickens' and piglets' body weight gain, decrease level of diseases and improve organoleptic indicators of carcasses of broiler chickens. Due to the content of various biologically active substances herbal preparations have antimicrobial, immunostimulating, general health improving effect on an animal's organism. Phytopreparations are used to improve digestion, enhance immunity, growth and reduce morbidity of animals. Phytopreparations are used as bactericidal medications for prevention and treatment of infectious diseases. With prophylactic and curative aim are used phytodactylos, such as "Fitovet", "Aciprogentin" $i$ "Progentin", "Species chamomillae SPOFA". Galega orientalis, Origanum vulgare, species of the genus Philadelphus and other medical plants that contain a huge amount of flavonoids and essential oils. They have bactericidal properties and can be used for prophylactic and treatment of diseases and air disinfections on farms. Unfortunately, we still do not know much about the herbal treatment of animals. The modern veterinarian does not have enough knowledge about the possibilities of using medicinal plants in veterinary medicine.

Key words: extracts of medicinal plants, herbal preparations, phytodactyles, veterinary medicine, pig breeding, poultry farming, fish farming, livestock breeding.

\section{Ветеринарна медицина і використання лікарських рослин}

\author{
І. Саламон ${ }^{1}$, М. Грицина ${ }^{2}$ \\ ${ }^{1}$ Прямівський університет у м. Пряшеві, Словакія \\ ${ }^{2}$ Львівський національний університет ветеринарної медицини та біотехнологій імені С.3. Гюсицккого, \\ м. Львів, Україна
}

В статті розглянуто історію становлення ветеринарної медицини в Східній Свропі (Австро-Угоричні) та Украӥні, починаючи з Середньовіччя, до наших днів. Особливу увагу приділено історії застосування рослин у ветеринарній практиці. Лікування рослинами тварин в минулому описано з архівної книжки Мартіна Чеха “Книга про лікування коней” (Будапешт, 1797 рік). Проведено аналіз сучасної літератури з питання використання лікарських рослин у ветеринарії. В основному, їх застосовують як фітодобавки до кормів - як альтернативу антибіотикам, барвниками чи іншим синтетичним препаратам у свинарстві, птахівництві, рибництві, молочному скотарстві, а також для зменшення бактеріологічного забруднення продуктів харчування, кормових добавок та ветеринарних препаратів. Це поліпиить екобезпеку продукції тваринництва. Рослинні препарати завдяки вмісту різних біологічно - активних речовин мають антимікробну, імуностимулюючу, загальнозміцнюючу дію на організм тварини. Фітопрепа- 
рати використовують для поліпшення травлення, змічнення імунітету, вони пришвидиують ріст та зменшують захворюваність тварин. Як бактериџидні препарати їх використовують для профілактики та лікування інфекційних захворюваннях. На жаль, ми ще мало знаємо про лікування рослинами тварин і сучасний ветеринар не має достатніх знань про можливості використання лікарських рослин у ветеринарії.

Ключові слова: екстракти лікарських рослин, рослинні препарати, фітодобавки, ветеринарна медицин, свинарство, птахівниитво, рибництво, молочне скотарство.

\section{Вступ}

Фітотерапія - це лікування рослинами або лікарськими формами, виготовленими безпосередньо з рослин. Фітотерапія забезпечує широкий спектр застосування лікарських рослин з метою профілактики захворювань; як основне лікування при неважких захворюваннях; для підтримуючого лікування поряд 3 використанням високоефективних хімічних препаратів, а також для поліпшення смакових властивостей препарату. Фармакологічна дія зумовлена вмістом різних активних інгредієнтів у рослинах.

Лікарські рослини також можуть стати важливою сировиною для виготовлення ветеринарних лікарських засобів. Такі препарати, звичайно, відрізняються від тих, що використовуються в гуманній медицині, що зумовлене фізіологічними особливостями і способом життя домашніх тварин. Профілактика та лікування домашніх тварин також $є$ серйозною проблемою великомасштабного тваринництва, де переважає масове розведення і спільне утримання домашніх тварин, а, отже, існує велика імовірність поширення захворювань, які можуть проявлятися в більш широкому діапазоні.

Ми мало знаємо про лікування тварин рослинами. Існує невелика кількість літературних джерел на цю тему. Тому метою даної роботи є вивчення історичного та сучасного досвіду використання лікарських рослин для лікування тварин.

\section{Матеріал і методи досліджень}

Матеріалом для написання статті були літературні джерела бібліотеки Пряшівського університету i Національної наукової бібліотеки у м. Пряшеві та Національної наукової бібліотеки імені Василя Стефаника НАН України у м. Львові. При проведенні досліджень використано методи: аналітичний, хронологічний, порівняльно - історичний.

\section{Результати та їх обговорення}

Історія лікування тварин 3 використанням лікарських рослин. Рослинами люди лікувалися 3 сивої давнини. Звичайно, лікування тварин, як і людей, в минулому не було раціональним. У лікувальній практиці використовувалися народні повір'я, забобони, лікувальні міфи, заклинання i невиправдані хірургічні втручання. Лікарі лікували на основі власного досвіду та традицій. Перші повідомлення про лікування рослинами в Східній Свропі збережені ще 3 часів Трипілля (III тисячоліття до н. е.) і скіфського періоду (І тисячоліття до н. е.). 3 часів Київської Русі зберігся у вигляді витягу в бібліотеці Лоренцо Медічі (Флоренція) трактат "Мазі" княгині Євпраксії Мстиславівни, яка працювала над ним у 1130-1140 pp. Люди широко застосовували трави, про цілющі властивості яких знали наші предки слов'яни. 3 поширенням християнства народне знахарство відійшло на задній план, тимчасом як набуло популярності лікування рослинними оліями, яке використовували ченці. Монастирська медицина породила перші лікарні, найперші згадки про які належать до XI ст. Добре розвиненою в Середньовіччі була хірургія, що пов'язано частими 3 війнами. Промислова заготівля i культивування лікарських рослин, як пише Скибіцька M.I., 2014 почалася у XVIII столітті зі створеного 26 листопада 1915 року на Лубенських землях "аптекарського городу”, а наступного року там була організована перша в Україні дослідна станція культури лікарських рослин, яка існує донині.

Щодо лікування тварин рослинами, то відомості $€$ значно обмеженими, інформацію про лікування тварин рослинами можна почерпнути 3 різних старих атласів, підручників або посібників. Дещо пізніше в Європі з'явилася спеціалізована література, наприклад книга Мартіна Чеха "Книга лікування коней”, яка була опублікована у 1797 в Будапешті (Witteková, 2008). Видання спиралося на практику турецьких цілителів і вітчизняні традиції. 3 великої кількості відомостей про лікарські рослини, що використовувалися в минулому для лікування тварин, була обрана інформація про найбільш поширені види рослин. Відвар 3 коренів ангеліки лікарської (Angelica archangelica L.) використовували при серцевих захворюваннях, а кори вільхи (Alnus glutinosa L. Gaertn.) давали при лихоманці. Квіти і плоди бузини (Бузина чорна L.) використовували як сечогінний засіб у тварин і проти глистів кишківника. Морозник фіолетовий (Helleborus purpurescens L.) був добрим засобом для очищення крові та при відсутності апетиту. Бедринець ломикаменевий (Pimpinella saxifraga L.) також мав широке застосування в лікуванні тварин і використовується як шлунковий, відхаркувальний і сечогінний засіб. Ялівець козачий (Juniperus sabina L.) широко застосовувався при різних показаннях, таких як анорексія, серцева слабкість, респіраторні захворювання, включаючи легеневі хвороби, входив до складу таких препаратів, як - лаксан, кармінатив, що використовуються як проносний засіб, при здутті та проти круглих червів у дорослих тварин. Часник, цибуля разом з насінням гарбуза давали проти нематод. Квітки дивини скіпетровидної (Verbascum densiflorum Bertol.) - при втраті апетиту, особливо у коней. Дубові листки і кору (Quercus robur L.) дуже часто використовували для лікування діареї у тварин, 
промивання гнійних ран. Коріння тирличу жовтого (Gentiana lutea L.), застосовуються для лікування захворювань печінки, легень, жовтяниці, при втраті апетиту та проти глистів. Живокіст лікарський (Symphytum officinale L.) використовувався для загоєння переломів, боротьби з запаленням і болями, для полегшення дискомфорту і навіть для заспокоєння кобил при спарюванні. Копитник європейський (Asarum europaeum L.) вводили у разі неспокою, при захворюванні серця, а великі дози -як засіб для викликання блювоти.

3 інших рослин любисток лікарський (Levisticum officinale Koch) був визнаний як сечогінний, вітрогінний і шлунковий засоби. Часто використовували насіння льону (Linum usittatissimum L.), з якого вітискали олію і використовували для лікування ран, опіків, а також застосовували при задишці тягових тварин. Чистотіл звичайний (Chelidonium majus L.) застосовували при захворюваннях легенів і печінки, а подрібнені свіжі рослини проти бородавок та інших шкірних захворювань. Перстач прямостоячий (Potentilla erecta L. Rausche) наносили на слизові оболонки, шкіру й очі, як і очанку (Euphrasia rostkoviana Hayek), котру також використовується для очищення крові. Відома медунка лікарська (Pulmonaria officinalis L.) застосовується для лікування захворювань легень, лепеха звичайна (Acorus calamus L.) при захворюваннях шлунково-кишкового тракту, особливо при шлункових і захворюваннях печінки та легень. Листки печіночниці звичайної (Hepatica Nobilis Garsautl) використовували при розладах травлення та при здутті у великої рогатої худоби. Грицики звичайні (Capsella bursa-pastoris L. Medic.) - як сечогінний засіб, також при сечовипусканні 3 кров'ю та припиненні кровотечі. Дуже поширеним засобом для лікування тварин була ромашка аптечна (Chamomilla recutita L. Rausch.), яку використовували при шлункових розладах, набряках, спазмах, подразнення очей, слизових оболонках і промиванні ран. Ревінь пальчастий (Rheum palmatum L.) застосовували для очищення крові, жовтяниці на ранній стадії, для поліпшення травлення. Як послаблюючий засіб і для промивання рани - парило звичайне (Agrimonia eupatoria L.). Гірчак пташиний (Polygonum aviculare L.) проявляє в'яжучі властивості, але також використовувалися його гемостатичні властивості, особливо при травмах коней. Дуже часто надземні пагони хвилівника звичайного (Aristolochia clematitis L.) використовували як спазмолітичний засіб при спазмах, коліках, його антисептичну дію - для загоєння ран, при запаленні очей, при легеневих хворобах. Проти внутрішніх i зовнішніх паразитів популярним є пижмо звичайне (Tanacetum vulgare L.). Барвінок малий (Vinca minor L.) використовувався проти раку у тварин. Про це згадується пізніше в офіційній медицині людини.

У деяких випадках рослини застосовували для підвищення продуктивності тваринництва. Так, цикорій звичайний (Cichorium intybus L.) використовували для прискорення росту молодих курчат. Для збільшення лактації у корів до корму додавали фен- хель звичайний (Foeniculum vulgare Mill.), кмин звичайний (Carum carvi L.) i козлятник лікарський (Galega officinalis L.) тощо.

Становлення сучасної ветеринарної практики i використання лікарських рослин. Як пише Присяжнюк В.Я. (Prysjazhnjuk, 2017): “Першими фахівцями лікувальної справи тварин у давні часи були пастухи, скотарі, вівчарі, коновали, а згодом - хірургицирульники. Для лікування тварин широко використовували народні засоби рослинного і тваринного походження".

Що стосується професійного використання лікарських рослин у ветеринарії, то варто зазначити, що перша ветеринарна школа на території АвстроУгорщини була заснована у Відні Марією Терезією у 1767 році і отримала назву "Інститут військових ковалів”, де також проводили лікування тварин. Ці ковалі лічили тварин у недалекому минулому в селах, а їхні німецькі "kurschmidt" або угорська назва “gyógykovács" (“лікуючий коваль”) збереглася до наших днів. Згодом - у 1782 році було створено перший ветеринарний коледж у Будапешті. Віхою в професійному лікуванні тварин було прийняття Закону 1888 року, який передбачав, що тільки випускник цього коледжу може займатися офіційною ветеринарною практикою. 3 іншого боку, варто визнати, що “лікуючі ковалі" вищезгаданих цілителів мали багатий досвід використання лікарських рослин і добре знали природу.

В контексті розвитку ветеринарної медицини в Східній Свропі слід розглянути історію розвитку ветеринарної медицини в Галичині, зокрема у Львові, де в 1512 році створюється цех хірургів, основною структурною одиницею якого була створена раніше Школа коновальства (ветеринаріі). Класична університетська кафедра ветеринарної медицини була створена у 1784 році на медичному факультеті Львівському університеті. На початку 1881/1882 навчального року у Львові була відкрита самостійна Цісарськокоролівська Ветеринарна школа. У вересні 1908 року вона отримала право надавати наукові ступені - доктора ветеринарної медицини, а за особливі заслуги звання почесного доктора і проіснувала до осені 1939 року. У 1944 році навчальний заклад поновив свою діяльність. У 1992 році повернуто попередню назву Львівська академія ветеринарної медицини. У 2003 році академії присвоєно статус національної та надано ім'я її вихованця і довголітнього працівника, видатного вченого, професора Степана Гжицького, а згодом й надано статус університету.

Сьогодні ветеринарна медицина є досить розвинутою. На жаль, ми можемо констатувати той факт, що сучасний ветеринар не володіє достатніми знаннями про можливості використання лікарських рослин у ветеринарній практиці. В Україні написано ряд посібників та підручників для студентів 3 використання лікарських рослин у ветеринарній медицині (Rabinovich, 1987; Dahno \& Dahno, 2012; Malyk et al., 2016). Проте наукових досліджень 3 цього питання ще недостатньо. 
У “Державній Фармакопеї України. Друге видання, доповнення”, 2018 вперше основна увага приділяється питанню контролю якості лікарських засобів для застосування у ветеринарній медицині на рівні вимог Свропейської Фармакопеї. В неї входить такий перелік лікарської рослинної сировини та лікарських рослинних препаратів, що застосовуються у ветеринарній медицині: акація, акебії стебла, андрографіса трава, астрагалу монгольського корені, берези листя, верби кори екстракт сухий, вовконога блискучого трава, вовчуга корені, вовчуга польового корені, гіркокаштана насіння, гіркокаштана насіння екстракт сухий, стандартизований, гірчака гостролистого кореневища та корені, гірчака східного плоди, дуба кора, дудника даурського корені, дудника китайського корені, дудника пушистого корені, коїксу насіння, ліщини листя, ломиносу арманда стебла, мускатного горіха олія, найолієва олія, цинеольний тип, нероліолія, повою (дерези) плоди, римської ромашки квітки, сосни карликової олія, суховершків звичайних супліддя-колоски, цмину піскового квітки, шавлії лавандолистої олія, шавлії мускатної олія, шоломниці байкальської корені, ялівцева олія.

Останнім часом у зв'язку з забороною країнами Європейського Союзу використання антибіотиків стимуляторів росту в годівлі тварин, через шкідливий вплив на здоров'я людей продукції тваринництва, постає питання заміни їх на безпечніші препарати чи кормові добавки, якими можуть бути лікарські рослини. Кормові добавки визначаються Європейською Директивою про кормові добавки 70/524 як речовини або препарати, що містять будь-які інгредієнти, що при додаванні до корму впливають на його властивості та виробництво екобезпечної продукції тваринництва.

3 цією метою можна використовувати і лікарські рослини, що є джерелом біологічно - активних речовин, зокрема ефірних олій, флавоноїдів, які мають антимікробну, імуностимулюючу, загальнозміцнюючу дію. Вони запобігають виникненню резистентності мікроорганізмів, не викликають алергічних реакцій, стимулюють імунітет, поліпшують травлення, а відповідно пришвидшують ріст тварин і знижують імовірність їхнього захворювання.

У свинарстві існує досвід використання насіння розторопші плямистої (Silybum marianum L.) як фітобіотичної добавки супоросним свиноматкам, що позитивно впливало на формування плодів поросят, малі поросята швидше привчалися до самостійної підгодівлі комбікормом і мали кращі середньодобові прирости живої маси. Колесник М.Д. (Kolesnyk \& Ban'kovs'ka, 2010) рекомендує ï̈ для масового використання у племінному та промисловому свинарстві.

3 літератури відомий (Bukalova \& Prylipko, 2013) досвід використання лікарських рослин у тваринництві для поліпшення лактації у корів та якості молока, яка залежить передовсім, від пригнічення активності його мікрофлори. Як альтернативу використанню 3 цією метою продуктів органічного синтезу, що додають у молоко, автори пропонують підгодовування тварини рослинами, зокрема травою деревію (Achillea millefolium L.), елеутерококом (Eleutherococcus senticosus), буркуном лікарським (Melilotus officinalis (L.) Pall.), борщівником Сосновського (Heracleum sosnowskyi Manden.), левзеєю сафлоровидною (мараловий корінь) (Rhaponticum carthamoides Willd.), цикорієм диким (Cichorium intybus L.), знітом вузьколистим (Epilobium angustifolium L.), материнкою звичайною (Origanum vulgare L.), обліпихою крушиноподібною (Hippophae rhamnoides L.), а також зеленою масою і насінням кропу (Anethum graveolens L.), фенхелем звичайним (Foeniculum vulgare Mill.), кмином звичайним (Carum carvi L.). Ці рослини посилюють апетит, біохімічні процеси травлення кормових мас, підсилюють фітоестрогенами гормональні функції лактуючої тварини, запобігаючи розвитку гнійної мікрофлори у травному каналі.

У птахівництві як фітодобавку до кормів Передеpa С.Б. і Кінаш О.В. (Peredera \& Kinash, 2013) пропонує використовувати екстракт ехінацеї пурпурової (Echinacea purpurea (L.) Moench.), що зумовлює підвищення живої ваги, яйценосності, збереженості поголів'я птиці. Бородай В.П. (Borodaj et al., 2011) запропонував чорнобривці прямостоячі (Tagetes erecta L.), які стимулюють пігментний обмін у курей, використовувати у годівлі курчат-бройлерів. Внаслідок цього їхня шкіра стає жовтою, а, як відомо, жовтозабарвлені тушки користуються на ринку великим попитом. Автором було встановлено, що при додаванні порошку з квіток чорнобривців до корму курчатам їхня жива маса збільшувалася на 115 г, а пігментація шкіри майже у 2,5 разу була інтенсивніша, ніж у контрольної групи. Використання чорнобривців як альтернативи штучним барвникам викликає потребу виготовляти з них фітопрепарат на промисловій основі.

Ефективність використання кормових добавок доведена в рибництві. Введення однорічкам коропа до кормів спиртової настойки ехінацеї пурпурової (Echinacea purpurea) зумовлює незначне збільшення у крові концентрації гемоглобіну, кількості еритроцитів та зростання вмісту альбумінів у сироватці крові, а отже, може сприяти збільшенню приростів риби (Deren', 2009). Високі показників приросту маси i поліпшення морфологічних показників деяких органів спостерігали у риб, яким згодовували розмелені плоди розторопші (Silybum marianum L.) (Korylyak, 2015).

Актуальним $\epsilon$ використання рослин як антимікробних агентів, оскільки мікробна забрудненість продуктів харчування, кормових добавок та ветеринарних препаратів залишається досить високою. Дослідженнями (Darmohray et al., 2018) встановлено, що водний екстракт Galega orientalis (Lam) має інгібуючий вплив в межах 20-30\% на ріст бактерій штаму Escherichia coli XL1, DH5, тимчасом як дія на бактерії штаму Micrococcus luteus та дріжджі Saccharomyces cerevisiae W303 була дещо нижчою.

Перспективним є використання у ветеринарній практиці чубушника (Philadelphus) як антимікробного препарату завдяки наявності фенольних сполук. Так, Іщенком В. (Ishchenko et al., 2016) було встановлено, 
що вміст фенолів у екстрактах чубушників становить $33,0 \pm 0,48$ до $107,1 \pm 0,91$ мг/гр. Вміст флавоноїдів у спиртових екстрактах листків коливається 5,3 $\pm 0,41$ до 10,6 \pm 0,41 мг/гр. Найбільш перспективним для використання є Philadelphus coronarius Nana' i Philadelphus L. 'Avalanche', які мають високу концентрацію флавоноїдів за відносно невисокого вмісту фенолів. 3 цією метою можна використовувати екстракти видів роду_Verbascum L., які також містять флавоноїди i кумарини та мають антимікробну дію (Hrytsyna, 2017).

Сильні антимікробні властивості мають ефірні олії, екстраговані з рослин, завдяки чому їх можна використовувати для дезінфекції та санації повітря, що дає змогу дотримуватися санітарно-гігієнічного режиму приміщень. Так, санація повітряного середовища птахівничих приміщень ефірними оліями м'яти перцевої (Mentha × piperita L.), шавлії лікарської (Salvia officinalis L.), фенхеля (Foeniculum vulgare) в дозі 0,025 мл/ $\mathrm{M}^{3}$ забезпечує протягом доби зниження бактеріального обсіменіння повітря на 63,2\% (Svintyc'ka, 2013).

Для профілактики і лікування гельмінтозів у тварин Лазоренко, 2017 пропонує використовувати рослини, які є менш токсичні для організму тварини.

Для поліпшення травлення й лікування шлунковокишкових захворювань (Sereda et al., 2012) було розроблено лікувально-профілактичний засіб “Фітовет”. Основними складовими збору є: ромашка лікарська (Matricaria recutita L.), звіробій звичайний (Hypericum perforatum L.), деревій звичайний Achillea millefolium L.), полин гіркий (Artemisia absinthium L.), злинка канадська (Erigeron canadensis L.), дуб черешковий (Quercus robur L.). Препарат у формі стерилізованого чи свіжоприготовленого відвару показав свою ефективність при дисбактеріозі, диспепсіях, дизентерії тварин.

У рамках нової пропозиції фірма MEVAK, a.s. Nitra пропонує деякі комбіновані препарати (Aciprogentin i Progentin), до складу яких входить порошок коренів аїру тростинового (Acorus calamus L.). Окрім того, Aciprogentin містить Natrii propionas $50,000 \mathrm{~g}$, Natrii hydrogenphosphas - 10,000 g. Це порошок брудно-коричневого кольору для перорального використання, призначений для великої рогатої худоби, овець та кіз. Progentin: Natrii propionas $120 \mathrm{~g}$, Calcii propionas $95 \mathrm{~g}$, Mangani sulfas monohydricum 0,5 g, Cupri sulfas pentahydricum 0,25 g, Ferri sulfas hexahydricum 0,0625 g, Cobalti chloridum hexahydricum $0,025 \mathrm{~g}$, Zinci sulfas heptahydricum $0,025 \mathrm{~g}$, біло-жовтуватий гігроскопічний порошок 3 поодинокими кольоровими кристалами мінеральних солей, призначений для великої рогатої худоби, телят, овець, кіз, свиней, собак.

Slovakofarma, a.s. Hlohovec виробляє препарат ромашки аптечної (Matricaria recutita L.) (Species chamomillae SPOFA), який володіє спектром речовин, що сприяють зменшенню спазмів гладких м'язів травної системи та використовуються для зовнішнього застосування (шкіри та слизових оболонок), пов'язаних $з$ протизапальною дією.

Рослинні кормові добавки 3 антимікробною активністю корисні для захисту здоров'я сільськогосподарських тварин. Такими добавками до корму є екстраговані з рослин ефірні олії, наприклад, материнки звичайної (Origanum vulgare L.) або чебрецю звичайного (Thymus vulgaris L.), які можуть бути альтернативою антибіотикам. У Словаччині отримано внутрішній стандарт “Добавка для комбікорму на основі материнки звичайної”, автор - Маріан Деметра. Стандарт поширюється на виготовлення, випробування, оцінку та реалізацію “комбікормової добавки на основі Origanum vulgare L.”, призначеної як кормова добавка для поросят - сисунів і відлучених поросят.

Хоча в останні роки зростає інтерес у практикуючих ветеринарних лікарів та науковців до лікування травами і рослинними препаратами, але він ще незначний. Так, ряд авторів (Sereda et al., 2012; Palapa et al., 2016) називають причини, які перешкоджають застосуванню лікарських рослин у тваринництві, зокрема: відсутність ветеринарних препаратів на основі лікарських рослин вітчизняного виробництва, недостатня сировинна база, особливо культивованих лікарських рослин, нерозвинута фітотерапія, незручність їх застосування у нативному вигляді в реальних умовах тваринницьких господарств, незацікавленість органів державного та місцевого управління у використанні лікарської продукції в тваринництві.

\section{Висновки}

В статті розглянуто історію становлення ветеринарної медицини в Східній Свропі (Австро-Угорщині) і Україні та історію використання рослин у ветеринарній практиці. Лікування рослинами тварин в минулому описано 3 архівної книжки Мартіна Чеха “Книга про лікування коней” (Будапешт, 1797 р.).

В сучасній ветеринарії як фітодобавки до кормів використовують рослини і їхні екстракти, зокрема Silybum marianum, Echinacea purpurea, Tagetes erecta, Galega orientalis, види роду Philadelphus, Origanum vulgare та інші, а також фітопрепарати "Фітовет", "Aciprogentin" i "Progentin", "Species chamomillae SPOFA" як альтернативу антибіотикам, барвниками чи іншим синтетичним препаратам у свинарстві, птахівництві, рибництві, молочному скотарстві для поліпшення якості молока та дезинфекції повітря на фермах. Використання рослинних препаратів поліпшують якість продукції тваринництва.

Рослинні фітопрепарати завдяки вмісту різних біологічно - активних речовин мають антимікробну, імуностимулюючу, загальнозміцнюючу дію на організм тварин. Фітопрепарати використовують для поліпшення травлення, зміцнення імунітету, як бактерицидні препарати для профілактики та лікування інфекційних захворюваннях.

На жаль, ми мало знаємо про лікування рослинами тварин і сучасний ветеринар не має достатніх знань 
про можливості використання лікарських рослин у ветеринарії.

\section{References}

Borodaj, V.P., Vertijchuk, A.I., Mel'nyk, V.V., \& Ponomarenko, N.P. (2011). Sposib pidvyshhennja jakosti m'jasa kurchat-brojleriv. Zb. nauk. pr. Vinnyc'k. nac. agrarn. un-tu: Serija: Sil's'kogospodars'ki nauky, 11(51), 3-5 (in Ukrainian).

Bukalova, N., \& Prylipko, T. (2013). Pidvyshhennja jakosti moloka ta produktyvnosti laktujuchyh koriv na osnovi etologichnyh pryncypiv. Tvarynnyctvo Ukrai'ny, 4, 1518. http://nbuv.gov.ua/UJRN/TvUkr_2013_4_8 (in Ukrainian).

Dahno, I.S., \& Dahno, G.P. (2012). Likars'ki ta otrujni roslyny z osnovamy fitoterapii' : navch. posib. Sumy: PP Vinnychenko M.D., FOP Lytovchenko Je.B. (in Ukrainian).

Darmohray, L., Gutyj, B., \& Darmohray, O. (2018). Koncepcija antymikrobnoi' aktyvnosti vodnogo ekstraktu roslyny Galega orientalis (Lam). Nauk. visnyk LNU veterynarnoi' medycyny ta biotehnologij. Serija: Veterynarni nauky, 20(87), 122-125. doi: 10.15421/nvlvet8724 (in Ukrainian).

Deren', O.V. (2009). Vplyv ehinacei' purpurovoi' na dejaki gematologichni ta biohimichni pokaznyky krovi odnorichok koropa. Rybogospodars'ka nauka Ukrai'ny, 4, 130-133 (in Ukrainian).

Derzhavna Farmakopeja Ukrai'ny. Derzhavne pidpryjemstvo "Ukrai'ns'kyj naukovyj farmakopejnyj centr jakosti likars'kyh zasobiv". 2-e vyd. Dopovnennja 3. Harkiv: Derzhavne pidpryjemstvo "Ukrai'ns'kyj naukovyj farmakopejnyj centr jakosti likars'kyh zasobiv" (in Ukrainian).

Hrytsyna, M.R. (2017). Vmist biologichno-aktyvnyh rechovyn u riznyh vydiv rodu Verbascum L. Scientific Messenger of LNU of Veterinary Medicine and Biotechnologies. Series: Veterinary Sciences, 19(77), 86-91. doi: 10.15421/nvlvet7720 (in Ukrainian).

Ishchenko, V., Kostenko, S., Kostenko, V., \& Tymoshyk, Y. (2016). Perspektyvy zastosuvannja chubushnyka jak likars'koi' roslyny. Nauk. visnyk LNU veterynarnoi' medycyny ta biotehnologij. Serija: Veterynarni nauky, 18(3(70), 123-127. doi: 10.15421/nvlvet7029 (in Ukrainian).

Kolesnyk, M.D., \& Ban'kovs'ka, I.B. (2010). Fitobiotychnyj stymuljator velykoplidnosti porosjat. Visnyk Poltavs'koi' derzhavnoi' agrarnoi' akademii', 2, 67-69 (in Ukrainian).
Koryljak, M.Z. (2013). Fitoterapevtychni vlastyvosti roztoropshi pljamystoi' ta i'i' vykorystannja $\mathrm{v}$ godivli tvaryn. Rybogospodars'ka nauka Ukrai'ny, 4, 97-108. http://nbuv.gov.ua/UJRN/rnu_2013_4_12 (in Ukrainian).

Korylyak, M.Z. (2015). Morfologichna harakterystyka kyshkivnyka ta gepatopankreasu dvolitok koropa pry zastosuvanni rozmelenyh plodiv roztoropshi pljamystoi'. Nauk. visnyk LNU veterynarnoi' medycyny ta biotehnologij. Serija: Veterynarni nauky, 17(3), 218-223. https://nvlvet.com.ua/index.php/journal/article/view/55 0 (in Ukrainian).

Lazorenko, L.M. (2017). Vykorystannja likars'kyh roslyn za parazytoziv u tvaryn. Visnyk Sums'kogo nacional'nogo agrarnogo universytetu Serija "Veterynarna medycyna", 11(41), 131-134 (in Ukrainian).

Malyk, O.G., Vlizlo, V.V., Kocjumbas, I.Ja., Salyga, Ju.T., Muzyka, V.P., Kosenko, Ju.M., \& Brezvyn, O.M. (2016). Likars'ki roslyny u veterynarnij medycyni. Kyi'v: Agrarna nauka (in Ukrainian).

Palapa, N.V., Pron' N.B., \& Ustymenko, O.V. (2016). Osoblyvosti vykorystannja likars'kyh roslyn u tvarynnyctvi. Zbalansovane pryrodokorystuvannja, 2, 47-50 (in Ukrainian).

Peredera, S.B., \& Kinash, O.V. (2013). Dosvid vykorystannja ehinacei' purpurovoi' u ptahivnyctvi. Visn. Poltav. derzh. agrarn. akademii': nauk.-vyrobn., fahovyj zhurn, 6, 62-68 (in Ukrainian).

Prysjazhnjuk, V.Ja. (2017). Parostky likuval'noi' spravy tvaryn v Galychyni. Naukovyj visnyk LNUVMBT imeni S.Z. G'zhyc'kogo, 19(77), 158-161. doi: 10.15421/nvlvet7734 (in Ukrainian).

Rabinovich, M.I. (1987). Lekarstvennye rastenija v veterinarnoj praktike: Spravochnik. Moskva: Agropromizdat (in Russian).

Sereda, A.V., Glushhenko, L.A., \& Gryshhuk, A.V. (2012). Perspektyvy vykorystannja likars'kyh roslyn i fitopreparativ u tvarynnyctvi. Veterynarna medycyna Ukrai'ny, 11, 40-41. http://nbuv.gov.ua/UJRN/ vetm_2012_11_15. (in Ukrainian).

Skybic'ka, M.I. (2014). Istorija vyvchennja likars'kyh roslyn v Ukrai'ni. Praci naukovogo tovarystva im. Shevchenka. Ekologichnyj zbirnyk, 39, 163-180 (in Ukrainian).

Svintyc'ka, K.V. (2013). Vykorystannja likars'kyh roslyn u procesi sanacii' povitrja ptahivnychyh prymishhen'. Visnyk Poltavs'koi' derzhavnoi' agrarnoi' akademii, 1, 171-173. doi: 10.31210/visnyk2013.01.42 (in Ukrainian).

Witteková, C. (2008). Př́rodná léčba koní. Praha: Nakladatelství Slovart (in Czech). 